DOI:10.32703/2415-7422-2020-10-1(16)-72-87

UDC 625.1' 62-1/9' 62-831.1

\author{
Mykola Ruban \\ JSK «Ukrzaliznytsia» \\ 5, Gedroitsa Ezhy St., Kyiv, Ukraine, 03680 \\ e-mail: nikolas.kindle@gmail.com \\ https://orcid.org/0000-0002-6396-4531
}

\title{
Prerequisites of formation and development of mainline electric locomotives engineering at the Luhansk diesel locomotives engineering plant
} (1957-2014)

\begin{abstract}
In the article an attempt to investigate in a chronological order the historical circumstances of the formation and development of the mainline electric locomotives engineering at the Luhansk diesel locomotives engeneering plant (19572014) has been made. The circumstances of the activity of the electric locomotives workshop of the Luhansk plant (1957-1967), within which the production of crew parts and units of the legendary locomotives VL8 and VL10 for Novocherkask and Tbilisi factories have been analyzed. In the late 1980s, due to the absence of a solid convertible currency for the import of traction rolling stock from Czechoslovakia in the wake of the economic crisis of the USSR, the Luhansk plant received orders for the development and production of self-propelled electric locomotives. However, with the proclamation of the Independence of Ukraine, due to the lobbying of the new government, promising projects of Luhansk electric locomotives were rejected, and the Dnipro electric locomotives engineering plant was defined the basic enterprise for the creation of mainline electric locomotives for the Ukrainian railways. Due to the unstable economic situation in the country and the lack of targeted financing, the Dnipro plant was unable to start mass production of a number of types of locomotives, HC «Luhanskteplovoz» together with the Novocherkask plant began production of freight electric locomotives on the technological basis of Russian locomotives. Further development and prospects of serial electric locomotives engineering at the Luhansk plant were interrupted by the aggravation of the militarypolitical situation in the region. However, it is clear that the historical experience of becoming a domestic scientific-production base of the mainline electrical production needs its proper understanding in the context of current tendencies of import of traction rolling stock with an attempt to localize its production in Ukraine.
\end{abstract}

Keywords: Luhansk diesel locomotives engineering plant; transport engineering; mainline electric locomotives engineering; Ukrainian railways 


\section{Introduction}

As, according to official data, the wear of the domestic electric locomotive fleet is more than $90 \%$, for a long time in Ukraine the issue of import of traction rolling stock has been actively considered, with the prospect of further localization of its production at Ukrainian enterprises. For the first time, the problem of updating a locomotive fleet arose in the early 1990s, when, in the absence of foreign exchange for the acquisition of a sufficient number of locomotives abroad, it was decided to combine imports with the organization of production of rail machinery at domestic factories (Moskalenko \& Mukminova, 1996, p. 94). Ukrainian engineering has a deep historical tradition. The first domestic locomotives of the tandem compound system were built based on the Odesa Railway Workshops of the South-Western Railways Society from 1894 to 1897 (Berdnychenko \& Kyrychenko, 2018, p. 288). At the end of the nineteenth century. Leading specialized centers of steam engeneering in Kharkiv and Luhansk were formed. In the postwar period (1947-1961) the staff of the Kharkiv transport engineering plant started a new era of locomotive building in the USSR, developing a sound technical base for the creation of most future series of locomotives of the Luhansk plant (Bystrichenko \& Dobrovolsky \& Drobotenko et al, 1995). The electric power industry in Ukraine was represented by specialized products of the Dnipro plant, which since 1958 produced shunting and industrial electric locomotives (Ruban \& Baka, 2020, p. 107). The Luhansk plant staff had extensive experience in the manufacture of electric locomotives, which in 1990 was commissioned by the Ministry of Railways of the USSR to develop their projects of freight passenger locomotives.

Unfortunately, for a long time the preconditions for the formation and the circumstances of the development of backbone electrical production in independent Ukraine have not found their comprehensive coverage in the national historiography, the exception is only the author's exploration. The history of the Luhansk diesel locomotives engineering plant and its products are presented in the monographs by G. Zhdanov, V. Rybinets, Y. Tsygankov-Serebriakov, V. Rakov, and A. Haruk (Zhdanov, 1981; Rybinets, 1996; Tsygankov-Serebryakov, 2006; Rakov, 1990, 1995, 1999; Haruk, 2019). However, these studies focus mainly on the Soviet period of the history of the plant, do not exhaust the completeness of the outlined topic and require the introduction of additional advanced scientific sources. The analysis on the history of production activity of the enterprises of the transport machine-building industry of Ukraine acquires its relevance on the background of the general reformation of the domestic industry, the need to update the traction rolling stock, taking into account the historical experience of solving the said issue.

Therefore, the subject of the proposed research is the production activity of the Luhansk diesel locomotive engeneering plant, which provides for the following research problems: first, to consider the history of the functioning of the electriclocomotive shop of the Luhansk Plant (1957-1967); secondly, to investigate the attempt to develop promising Luhansk electric locomotives against the background of 
the formation of domestic electric locomotive engeneering in independent Ukraine (1991-1993); thirdly, to trace the circumstances of the introduction of the mainline electric locomotives at the Luhansk plant in the composition of Russian beneficiary company (2004-2014). The chronological boundaries of the study cover the period from the beginning of the manufacture of electric locomotive`s units at the Luhansk plant in 1957 to the forced shutdown of the enterprise in 2014.

The purpose of the article is to reproduce a complete picture of the historical preconditions for the formation and circumstances of the development of the mainline electric locomotives at the Luhansk diesel locomotive engeneering plant, on the basis of a comprehensive analysis of historical sources, periodicals and scientific literature.

\section{Research Methods}

In writing the proposed intelligence, general scientific methods and principles of historical research were used, in particular, historicism, objectivity, continuity, multifactoriality, complexity and comprehensive knowledge (Fullerton, 2011), which made it possible to carry out a study of the historical preconditions for the formation and development of the mainline electric locomotives engeneering at the Luhansk diesel locomotive engeneering plant in clear chronological order.

\section{Results and discussion}

In 1953, the designers of the Novocherkask electric locomotives engineering plant developed and introduced into mass production the legendary N8 Series electric locomotive (from 1963 - VL8) with a power of $4200 \mathrm{~kW}$ (Rakov, 1995, p. 422). In February 1956, at the XX Congress of the CPSU, it was decided in the transport engineering to develop the production of electric locomotives and diesel locomotives and stop the production of mainline steam locomotives. The Congressional Directives set out to deliver at least 2000 electric locomotives over a five-year period, including 400 eight-axle locomotives with a capacity of $5700 \mathrm{hp}$, as well as 2250 mainline twosection locomotives. Ensure the creation of new powerful locomotives, design and manufacture in 1956-1957 experimental models of freight diesel locomotives with a capacity of 2500-3000 hp in one section, passenger diesel locomotives and electric locomotives, as well as gas-powered locomotives (Naporko, 1957, p. 371-372). October 19, 1956 Minister of Transport Engineering of the USSR S.O. Stepanov signed Order No. 284 concerning the renaming of the Voroshilovgrad steam locomotive engeneering plant into a diesel locomotive engeneering plant (Zhdanov, 1981, p. 131). On February 9, 1956, the company released its first diesel locomotive - TE3-2001, and at the end of December - the last steam locomotive LV-0522 (Rybinets, 1996, p. 103, 116).

\section{The electric locomotives workshop of the Luhansk plant (1957-1967)}

During 1956 the main works on reconstruction of Voroshilovgrad plant, organization of specialized sites were completed. The metallurgical and other 
workshops were restructured, taking into account the extension of third-party orders, in particular, the steel shop was casting locomotives for the Novocherkask plant (Rybinets, 1996, p. 118). In mid-March 1957, the manufacture of electric locomotive parts began on the 6th span of the mechanical assembly shop. At the end of June 1957 the first two electric locomotive frames were delivered. The team of nonstandard equipment department took an active part in the restructuring of the former tendering and stocking in the locomotive shop, which did a great job of creating sections and lines for machining of locomotive parts, and also installed new highperformance equipment (Rybinets, 1996, p. 120).

Production of VL8 locomotives at the Tbilisi plant was started in 1957. As production increased, their production at the Novocherkassk plant began to decline, and from 1963 it ceased. The Novocherkask plant, as a basic electrical engineering company, has started the development of new electric locomotive designs, including VL80. The two-section crew of the VL8 locomotive consisted of four articulated two-axle carts with solid cast frames and axle roller bearings (Rakov, 1999, p. 21). Having no foundry production, the Tbilisi plant could not produce such trolleys, and their production at the Novocherkassk plant was already discontinued. In 1962, with the aim of assisting in the establishment of the Tbilisi plant, with the agreement of the line ministries, the Luhansk plant began to manufacture complete crew units for VL8 locomotives (Buyanov, 2005, p. 166). The cast frames of the trolleys were very complex and cumbersome, but the Luhansk foundries mastered their production, were molded in a large frame shop, and sent to a steel shop for molding of frame shapes. In 1961, the designers of the Tbilisi plant developed a $5200 \mathrm{~kW}$ VL10 electric locomotive, which was supposed to replace the VL8 locomotives (Rakov, 1999, p. 30). In 1962 a group of Luhansk designers was sent to Tbilisi. The teams of three factories participated in the construction of the crew unit of the VL10 locomotive: the carts were manufactured at the Novocherkask plant, the rest of the units were performed by the staff of the Luhansk plant (Buyanov, 2005, p. 166). The first specimens of the VL10 locomotives were unified on the body with the locomotive 2TE10L and the carts with the locomotive VL80. The mass production of bodies and units of electric locomotives VL10 at the Luhansk plant lasted until 1967 (Rakov, 1999, p. 33).

The Luhansk plant built two single-axle two-axle trolleys for the passenger electric locomotive of VL40, developed by the staff of the Special Design Bureau of the Tbilisi Plant (Buyanov, 2005, p. 167). While preparing the trolleys for production, the specialists encountered the unpredictable complexity of the individual components and components, conducting a number of unanticipated experiments. The difficulty was that the wheel diameter was $1250 \mathrm{~mm}$, while for all locomotives in the 1960s it was adopted $1050 \mathrm{~mm}$. Chief engineer of the plant N.M. Naish, refusing to make models, instructed the designers to work out a variant of manufacturing wheel centers from the forging. Trolley Bureau Chief Robertman R.M. and the crew of the electric locomotive VL10 Buianov A.F. Categorically opposed to this variant of the wheel center of the forging carts, since 
the machining would cut the metal fibers and would not have the strength. In worldwide practice, the rolling stock centers were made rolled or cast. The models under the two-wheel centers were nevertheless manufactured, molded parts, machined and assembled into wheel pairs. Trolley frames and gearboxes were sophisticated. Two carts were manufactured and shipped to Tbilisi (Buyanov, 2005, p. 167). In 1966 the first pilot electric locomotive VL40 was built, and in 1969 - the second one, which differed by types of traction motors. However, the low power of the locomotive (no more than $3200 \mathrm{~kW}$ ) did not satisfy the increased weight of passenger trains, which necessitated the ordering of the more powerful six-axle Czechoslovakian electric locomotives of CS4 (hourly power of $5100 \mathrm{~kW}$ ) (Rakov, 1999, p. 116).

In this regard, VL40 locomotives have not been introduced into mass production and operation. In the mid-1960s, the Tbilisi Plant created a new crew unit for the VL10 locomotive, based on the VL80 locomotive, to build the Novocherkask plant, which since 1967 has supplied crews to Tbilisi. New body types were installed on electric locomotives, starting with VL10-021 (Rakov, 1999, p. 33). In September 1967, the Tbilisi plant produced the last electric locomotive VL8-1723 and, due to the curtailment of the production of crew parts, the locomotive shop of the Luhansk plant was reorganized into a mechanical assembly shop No. 3.

\section{Perspective projects of freight-passenger electric locomotives EL-1 and EL-2}

For a long time, the fleet of passenger electric locomotives of the USSR was largely replenished by supplies from Czechoslovakia. Since 1989, the volume of imports of rail technology has started to decline significantly due to the lack of hard currency. Hence the need to expand the production of locomotives for electrified railways at one of the enterprises of the country. In the summer of 1990, a preliminary agreement was signed between the Ministry of Railways of the USSR and the Production Association «Luhanskteplovoz», and in early 1991, Deputy Minister B. D. Nikiforov signed an application for the creation of direct and alternating current electric locomotives. The annual issue had 100 locomotives each series. The conventional designation of an electric locomotive with a voltage of $25 \mathrm{kV}-\mathrm{EL}-1$, a direct current of $3 \mathrm{kV}-\mathrm{EL}-2$ (Ladyzhensky, 1992).

The project envisaged the use of the crew part of the locomotive TE136 - the length of one-section two-cab locomotive had to fit the dimensions of the locomotive section. It was planned to use high-power traction motors, as the design capacity of the locomotives was expected to be $8700 \mathrm{hp}$ vs. $6000 \mathrm{hp}$ the locomotive. In December 1991 in Moscow with the participation of the leading engineer of the electric locomotive M. G. Lozovoi was protected by a preliminary sketch project of the locomotive. At the beginning of 1992, the development of technical documentation for both modifications of the locomotive began. According to the contract the design was to be completed in January 1993, the production of the 
prototype of the electric locomotive EL-2 - in the 1st quarter of 1994, the EL1 - IV quarter of 1994 Lyman Donetsk Railway (Ladyzhensky, 1992).

Due to the fundamental differences between the technologies of electric locomotive engeneering, a new experimental production base was expected to be created. It was necessary to begin preparation of special equipment for checking electrical circuits, special punching devices at a voltage of 2.5 kilowatts, as well as to build devices for testing the lubricant cooling system of transformers, experimental verification of pantograph receivers and other units. During the creation of the locomotive, the design, technological and testing services of Luhanskteplovoz cooperated fruitfully with the All-Union Research Institute of Railway Transport (Moscow), the All-Union Scientific-Research Diesel Institute (Kolomna), and the Electric Company (Kharkiv). Transformer Research Institute (Zaporizhzhia) by Luhansk Mechanical Engineering Institute, etc. Advisory meetings were held with representatives of the Novocherkask plant. The management of the Luhansk plant confirmed its readiness to release new locomotives and hoped that demand for them would be high among the CIS republics (Ladyzhensky, 1992).

After the proclamation of the Independence of Ukraine, the question of coordination of main transportation on the territory of the republic arose. In order to effectively manage rail transport and meet the needs of the economy and the population in transportation, on December 14, 1991, the Cabinet of Ministers of Ukraine adopted a resolution «On Establishment of the State Railway Administration of Ukraine» - «Ukrzaliznytsia» (Moskalenko \& Mukminova, 1996, p. 8). In the early 1990's, the issue of transition of the whole network of Ukrainian railways to electricity was considered. At that time from $22700 \mathrm{~km}$ only $8400 \mathrm{~km}$ of railway lines were electrified. There was a need for the primary electrification of cargo-stretched sections - about $3000 \mathrm{~km}$. Ukrzaliznytsia developed the main provisions of the railway electrification program by 2005 , which was intended to electrify $1667 \mathrm{~km}$ of the track in the first place. The implementation of this program was to reduce the annual consumption of petroleum products by 454000 tons, to increase the transportation of goods by electric power on average from 64.5 to $75 \%$. The conversion of $1 \%$ of freight to electric traction reduced rail costs by 2.7 billion rubles annually for 1984`s prices (Moskalenko \& Mukminova, 1996, p. 21).

In July 1992, the Ministry of Mechanical Engineering, Military-Industrial Complex and Conversion approved the «Program of development of railway transport of Ukraine», calculated until 1998. During this time, the Luhansk plant had to establish the production of 7 new types of rail cars, including DC and AC electric locomotives, and the establishment itself provided for the creation of a test site for rolling stock testing (Krayevoy, 1992; Lozovoy, 1992). In order to coordinate the activities of manufacturers, scientific organizations and railways, a section of scientific and technical cooperation was established at «Ukrzaliznytsia», which included representatives of 6 Ukrainian railways, specialized departments of Ukrzaliznytsia, rolling stock manufacturers and railway systems. The functions of 
SNTS in the field of locomotive economy were: development, testing, commissioning of traction rolling stock, modernization of existing TRS, change of technology and rules of operation of TRS, development of safety systems on railways, etc. The first organizational meeting of the section took place in Luhansk on August 19, 1992, during which the priority terms of the stages of creation and serial production of new machinery were agreed (Krayevoy, 1992).

At the same time, the special design and technological bureau of the Dnepropetrovsk electric locomotive engineering plant, which specialized in the production of shunting and specialized industrial electric locomotives, was developing its own project of an eight-axle freight locomotive. Finally, following a change in the composition of the Government, during a series of technical meetings the projects of Luhansk electric locomotives were rejected (Zhuzhgin, 1993). On June 26, 1993, the Cabinet of Ministers of Ukraine approved Resolution No. 480 «On the Development and Production in 1993-2000 of Main Freight and Passenger Electric Locomotives», according to which the Scientific and Production Association «Dnepropetrovsk electric locomotive engineering plant» was designated as the main manufacturer of main freight and passenger electric locomotives plant (Postanova Kabinetu Ministriv Ukrayiny vid 26 chervnya 1993 no. 480 «Pro rozrobku i vyrobnytstvo u 1993-2000 rokakh mahistral'nykh vantazhnykh i pasazhyrs'kykh elektrovoziv»)). According to the plan, up to 2000, 230 DC electric locomotives, 85 $\mathrm{DC}$ direct electric locomotives, $80 \mathrm{AC}$ electric locomotives and $35 \mathrm{AC}$ electric locomotives were to be manufactured inclusive. The Dnipro SKTB was reorganized into the Ukrainian Research Institute of Electrical Locomotive Engineering (Gereilo, 1996). It envisaged a profound modernization of the Dnipro plant and institutions that were to be part of the state-owned electric engineering corporation Ukrelektrovoz, which had the responsibility of coordinating research and design work on the creation of main freight and passenger electric locomotives.

In the summer of 1996, the teams of SPA «DELEP» and USRI of Electrical Locomotive Engineering developed and built the first Ukrainian eight-axle mainline electric DC electric locomotive - DE1 with a power of $6260 \mathrm{~kW}$ (Likhushyn, 2018, p. 12). In the fall of 1996, the Deputy Director of UNI Electric Engineering V. Savysko announced the completion of the development of the passenger mainline electric locomotive DE2, in turn there should be series DE3 and DE4 (Gereilo, 1996), however, further development and introduction to the production of these models were discontinued. the lack of funding, despite the fact that in 1996 investing in the modernization of the electric locomotive fleet was identified as a priority in the overall sequence of calculations by Ukrzaliznytsia (Moskalenko \& Mukminova, 1996, p. 66). In 2002, the designers of the Dnipro plant together with the German concern Siemens created a universal passenger electric locomotive of alternating current - DS3 with power of $4800 \mathrm{~kW}$. It is noteworthy that the Russian company «Transmashholding» interfered with the demonstration of the Ukrainian-German locomotive at Russian exhibitions (Shvaiko, 2003). In 2003, the teams of SPA «DELEP» and USPI of 
electrical engineering were merged into the State Enterprise «Dnipropetrovsk Scientific and Production Complex «Elektrovozobuduvannia». Soon, SPC «Elektrovozobuduvannia», together with the Siemens concern, started to develop a two-engine DS4 locomotive at the speed of $200-220 \mathrm{~km} / \mathrm{h}$ on the basis of the electric locomotives DS-3 (Ruban \& Baka, 2020, p. 108, 110).

\section{Freight locomotives 2EL4 and 2EL5 (2005-2014)}

Another attempt of introduction of the mainline electric locomotive engeneering at the Lugansk diesel locomotive engeneering plant was connected with the privatization of the enterprise. In 1998, the first tender for the sale of shares of the Luhansk plant was announced, and in 2001, the State Property Fund of Ukraine put $76 \%$ of the plant's shares for sale. However, a number of attempts to privatize the controlling stake in the enterprise have remained unsuccessful (Yurova \& Spektor, 2011).

As the Dnipro plant did not set up production of domestic freight electric locomotive of alternating current, on December 1, 2004 a contract was signed between $\mathrm{HC}$ «Luhanskteplovoz» and Novocherkassk electric locomotive engineering plant to supply and organize production of 50 locomotives for the needs of Ukrzaliznytsia amounted to 100 million euros, which included the development of design and technological documentation, the production and testing of the first pilot electric locomotive, as well as the cost of sets of equipment for the manufacturers electric locomotives (Tsygankov-Serebriakov, 2006, p. 336). Release of the prototype of the locomotive was planned for August 2005. Starting from the second locomotive, the manufacture of most units, assembly and assembly of locomotives had to be carried out at the Luhansk plant when supplying sets of electric vehicles, traction and auxiliary electric machines manufactured by Novocherkask plant. As the production of part of the equipment at Ukrainian enterprises was mastered, the share of Russian equipment had to gradually decrease to $35-40 \%$ of the initial volume.

In December 2005, at the Novocherkask plant, together with the specialists of $\mathrm{HC}$ «Luhanskteplovoz», the first two-section electric locomotive with collector traction motors of 2EL5-001 developed on the basis of the Russian electric locomotive 2ES5K manufactured by the Novocherkask plant was manufactured. A distinctive feature of the 2EL5 electric locomotive was the modified control cabin with sloping buffer lanterns, elongated trapezoidal shape, united in a single block headlamp, designed by the Design Bureau of the Dnipro Innovation Company «International Business Cooperation». The electric locomotive was equipped with Ukrainian safety devices (Tsygankov-Serebriakov, 2006, p. 349).

On July 19, 2006, the State Property Fund of Ukraine again authorized the sale of 76\% of the shares of the Luhansk plant, and on March 23, 2007, the company was sold to the Russian company «Transmashholding» for \$ 58 million (Pavliuk, 2010). In December 2007, a series of acceptance tests for the 2EL5 electric locomotive was successfully completed, the main purpose of which was to confirm the strength characteristics of the machine and to determine the operational parameters 
(Borisenko, 2010, p. 8; Spektor, 2009). HC «Luhanskteplovoz» made the crew part, thus creating a minimal additional cost of production. The factory developed and commissioned an improved electric locomotive cart for the manufacture of which more than 120 pieces of equipment, stands, other equipment were introduced in the workshops, and new technologies of processing of complex components and parts were mastered (Borisenko, 2010). The first carts of Luhansk production were installed on electric locomotive 2EL5-008. As of 2008, the company was ready to manufacture up to 10 sets of carts and main frames of electric locomotives per month.

In October 2008, the Ministry of Transport of Ukraine approved the «Comprehensive program for updating the railway rolling stock of Ukraine for 20082020», which determined that for the organization of high-speed traffic by 2020 it is necessary to replenish the railway fleet of Ukraine by direct and alternating current electric locomotives 282 units, two-passenger passenger locomotives - 110 units. In 2008, the plant produced 18 sections of the 2EL5 electric locomotive (Spektor, 2009). As a result of 11 months of work in 2008, the enterprise's output amounted to UAH 1 billion, which became a record economic indicator for 17 years. Production growth was almost 200\%. In 2009, Ukrzaliznytsia's financial plan provided for the purchase of 6 electric locomotives from $\mathrm{HC}$ «Luhanskteplovoz». At that time, work on restructuring and optimization of the number of employees at the enterprise was conducted on the basis of the order of «Ukrzaliznytsia» (Osobova, 2009).

The global economic crisis of 2008 significantly complicated the position of railway engineering enterprises in Ukraine, in particular, SPA «Elektrovozobuduvannia». Supplies of DS3 electric locomotives sharply decreased: out of 101 planned units, only 18 were purchased (Hrebeniuk, 2009). In 2008, he received the certificate of conformity of the Russian electric locomotive 2ES4K of the Novocherkask plant development and the prospects of introducing mass production of its Ukrainian counterpart at the facilities of the Luhansk plant arose. Since the Dnipropetrovsk plant did not established serial production of the electric locomotive DE1 (all 40 locomotives were experimental), its electronics was morally outdated, and the cost of the Russian electric locomotive 2ES4K, taking into account transportation and customs clearance was lower than the cost of production DE1, a Dnipro electric locomotive couldn't stand the competition and its orders were ceased (Likhushyn, 2018, p. 14). According to «Ukrzaliznytsia» CEO Mikhail Kostiuk: «We are not satisfied with the belated policy of a domestic manufacturer who invests in the development of outdated technology» (Hrebeniuk, 2009). This meant that the products of the state-owned SPC «Elektrovozobuduvannia», in particular, created the project of a two-system electric locomotive DS-4, became completely uninteresting for the management of «Ukrzaliznytsia».

As the complex program of updating of the railway rolling stock of Ukraine envisaged the order of 110 two-way passenger electric locomotives with asynchronous drive, the heads of the Luhansk plant expressed their readiness to start developing such a locomotive. As part of the technical cooperation between the 
French machine-building company Alstom and the owner of the controlling stake in the Luhansk plant, «Transmashholding» developed a project for a passenger dualpropulsion electric locomotive EP20 at speeds up to $200 \mathrm{~km} / \mathrm{h}$ (Konovalov, 2010). «We have the necessary documentation and documentation. As soon as the prefinanced order appears, we will be able to make a prototype» said Viktor Bikadorov, General Director of HC «Luhanskteplovoz». According to him, the cost of building the prototype was at least 3 million euros (Hrebeniuk, 2009).

In March 2009, HC «Luhanskteplovoz», together with the Novocherkask plant, began production of two-section 2EL4 DC electric locomotives, developed on the basis of the Russian 2ES4K Donchak electric locomotive (Pervyy Luganskiy, 2009). The first prototype of locomotive 2EL4-001 was put into operation in Donetsk railway. The 2EL4 electric locomotive was as unified as possible with the 2EL5 electric locomotive. The electric locomotive was equipped with the latest traffic safety systems, the Ukrainian fire extinguishing and signaling system, a modern control cabin, a switch that provided high switching ability and long service life; three-phase asynchronous motors for the drive of cooling fans of traction motors, compressors powered by a static converter; fridge and plumbing equipment. Rated voltage of the control circuits $-110 \mathrm{~V}$. Basic parameters of the electric locomotive 2EL4: power in hour mode on the shafts of traction motors not less than $6400 \mathrm{~kW}$; design speed of $120 \mathrm{~km} / \mathrm{h}$; the thrust force in the hour mode - not less than 44 tons; load from the wheelset on the rails - 23.5 tons. Among the main structural advantages of the new machine were improved running properties, more efficient use of the coupling weight, reduction of harmful effects on the track, which reduced the wear of rails and bandages of wheel pairs. In addition, traction electrical equipment has been used to reduce cooling air consumption, while individual in-wheel ventilation on the basis of asynchronous motors has increased efficiency and reliability. In the wiring diagram, units of mainly domestic mass production were used, which made it easier to organize maintenance and repair at Ukrzaliznytsia locomotive depots (Pervyy Luganskiy, 2009).

At the beginning of November 2009, the decision of the Commercial Court of Luhansk region canceled the results of the privatization auction of the Luhansk plant (Pavlyuk, 2010). In the spring of 2010, French machine-building corporation Alstom Transport with a stake of $26 \%+1$ became one of the shareholders of the Russian company «Transmashholding», and already on June 15, 2010 Briansk mechanical engineering plant, which was a part of the «Transmashholding» Company, re-bought the stake of the Luhansk plant for \$ 51 million (Pavliuk, 2010). As one of the actual beneficiaries of the Luhansk plant was Alstom, the world's leading manufacturer of railway equipment, it was hoped that this factor would have a positive impact on the technological reconstruction of the enterprise (Yurova \& Spektor, 2011; Gerasimova, 2010).

During 2009, the Luhansk plant reduced production by three times, producing two electric locomotives - 2EL4-001 and 2EL5-013. In 2010, according to the signed 
financial plan, «Ukrzaliznytsya» planned to purchase 9 trunk electric locomotives from PJSC «Luhanskteplovoz» (5 DC and 4 AC), however, the plant released only two sections of the 2EL4 locomotive and six sections of the 2EL5 locomotive (Luganskim teplovozam - zelenyy svet, 2010). It is planned to produce 3 DC electric locomotives for the Donetsk railway in 2011 (Yurova \& Spektor, 2011). During January-September 2011 PJSC «Luhanskteplovoz» produced 4 sections of electric locomotives of both series («Luganskteplovoz» vypolnyayet zakazy RZHD, 2011).

In the spring of 2013, PJSC «Luhanskteplovoz» within the framework of the Decree of the Cabinet of Ministers of Ukraine on the renewal of the rolling stock of Ukrainian railways received a state order for the production of $300 \mathrm{DC}$ and AC freight locomotives. The estimated amount of the contract was estimated at over UAH 12 billion. There were plans to create a service center for servicing Luhansk locomotives on the basis of the Yasinovata Donetsk Railway locomotive depot. The plant has planned to purchase new machining and harvesting equipment to increase production volumes and improve the quality of work (Luganskteplovoz postavit Ukrzalíznitsí 300 elektrovozov, 2013). In the fall of 2013, PJSC «Luhanskteplovoz» signed an agreement with the Odessa Railway to supply 70 trunk electric locomotives of the 2EL5 series by 2017. Deliveries were to be divided into three years: in $2014-$ 5 units, in 2015 - 30 units, and in 2016 - 35 units. («Luganskteplovoz» pomozhet odessitam, 2013).

As part of the process of restructuring and concretization of production, interworkshop movement of equipment was carried out. At the meeting of the Interagency Commission, the final decision was made regarding the serial production of 2EL4 and 2EL5 electric locomotives. Designers and technologists worked out layout decisions on the installation of Ukrainian equipment on electric locomotives, organization of technological process of production in the shops of the plant. In November 2013, the last 4 sections of the 2EL4 electric locomotive were manufactured (PAO «Luganskteplovoz» narashchivayet tempy, 2013).

Unfortunately, with the start of hostilities in the spring of 2014, the economic activity of the Luhansk plant was complicated. In October 2014, the company resumed its production activity, and even managed to execute the plan as a result of the year. However, since the main customer of Luhansk electric locomotives was «Ukrzaliznytsia», due to the complicated military and political situation, the mainline electric locomotive engeneering at the enterprise was discontinued, but today only single sections of shops that perform mechanical processing of Novocherkask and Briansk plants parts are functioning.

\section{Conclusions}

Thus, for a long time Luhansk diesel locomotives plant, having a strong scientific and production potential, carried out the development and created unique samples of rail technology, including a new generation of electric locomotives and their units to meet the needs of the national locomotive park. Unfortunately, due to the traditional lack of 
financing of state orders and lobbying from both political groups and foreign machinebuilding enterprises, Luhansk locomotives have not become the main locomotives of Ukrainian railways. However, the analysis on the historical experience of the formation of the mainline electric locomotive engeneering in Ukraine is of fundamental importance both in the general perspective of the development of the Ukrainian industry, and of the railway industry in particular.

\section{References}

Berdnychenko, Y. \& Kyrychenko, H. (2018). Consultative congresses of the rolling stock and traction engineers: activity of L.M. Levi. Istoriia nauky i tekhniky History of Science and Technology, 8(2(13)), 284-296. https://doi.org/10.32703/2415-7422-2018-8-2(13)-284-296 [in Ukrainian].

Borisenko, G. (2010). Peremennaya i postoyannaya «Luganskteplovoza» [Variable and constant of «Luganskteplovoz»]. Ukrainskaya tekhnicheskaya gazeta Ukrainian technical newspaper. May 25. No. 21 (125). [in Russian].

Buyanov, A. F. (2005). Tvortsy novoy tekhnyky [Creators of new equipment]. Lugansk: Knyzhkovyy svit [in Russian].

Bystrichenko, A. V., Dobrovolsky, Y. I., Drobotenko, A. P. et al. (1995). KHPZ Zavod imeni Malysheva 1895-1995. Kratkaya istoriya razvitiya [KhPZ Malyshev factory. 1895-1995. A brief history of development]. Kharkov: Prapor [in Russian].

Fullerton, R. (2011). Historical methodology: the perspective of a professionally trained historian turned marketer. Journal of Historical Research in Marketing, 3(4), 436-448. https://doi.org/10.1108/17557501111183608.

Gerasimova, Ye. (2010). Frantsuzskiy vektor «Luganskteplovoza» [French vector of «Luganskteplovoz»]. Ukrainskaya tekhnicheskaya gazeta - Ukrainian technical newspaper. August 24. No. 33-34 (137-138). p. 5 [in Russian].

Gereilo, V. (1996). Budet li ukrainskoye elektrovozostroyeniye? [Will there be a Ukrainian electric locomotive engineering?]. Magistral, December 3(75(225). Kyiv, p. 1,3 [in Russian].

Haruk, A. I. (2019). Sdelano v Ukraine. [Made in Ukraine]. Kharkov: Folio [in Russian].

Hrebeniuk, Y. (2009). «Ukrzaliznytsya» ishchet elektrovoz [«Ukrzaliznytsia» is looking for an electric locomotive]. Ekonomicheskiye izvestiya - Economic news, November 16(206(1204). Kyiv, p. 4 [in Russian].

Konovalov, D. (2010). Lokomotyv na tupykoviy vittsi [Locomotive on a dead end branch]. Ukrayins'ka tekhnichna hazeta - Ukrainian technical newspaper. June 15(24 (128). p. 7. [in Ukrainian].

Krayevoy, S. (1992). Vyderzhim i etu dorogu zheleznuyu... [We can withstand this railway too...]. Oktyabrskiy gudok - October hooter. August 26. 50 (10329). Lugansk, p. 1. [in Russian]. 
Ladyzhensk, G. (1992). Sozdayetsya ukrainskiy elektrovoz [Ukrainian electric locomotive is being created]. Oktyabrskiy gudok - October hooter. February 4. No. 7(10287). Luhansk, p. 3 [in Russian].

Likhushyn, Y. V. (2018). Elektrovoz DE1: stvorennya i ekspluatatsiya [Electric locomotive DE1: creation and operation]. Locomotive inform. No. 11 (155). Kharkiv: Rukhomyy sklad, p. 12-16 [in Ukrainian].

Lozovoy, M. (1992). Dostoyno realizovat' vozmozhnosti [Worthy to implement opportunities]. Oktyabrskiy gudok - October hooter. 1992. August 26. No.52 (10331). Lugansk, p. 2 [in Russian].

Luganskim teplovozam - zelenyy svet [Lugansk diesel locomotives - green light] (2010). Ukrainskaya tekhnicheskaya gazeta - Ukrainian technical newspaper. July 13. No. 27 (131). p. 2 [in Russian].

«Luganskteplovoz» pomozhet odessitam [«Luganskteplovoz» will help Odessa residents] (2013). Nasha gazeta - Our newspaper. September 11. 131(3794). Lugansk, p. 2 [in Russian].

«Luganskteplovoz» postavit «Ukrzalíznitsí» 300 elektrovozov [«Luganskteplovoz» will supply to «Ukrzalíznitsya» 300 electric locomotives] (2013). Nasha gazeta - Our newspaper. May 21. 70(3733). Lugansk, p. 6 [in Russian].

«Luganskteplovoz» vypolnyayet zakazy RZHD [«Luganskteplovoz» fulfills orders of Russian Railways]. (2011). Ukrainskaya tekhnicheskaya gazeta - Ukrainian technical newspaper. October 11.39(194). p. 3 [in Russian].

Moskalenko, P. \& Mukminova, T. (1996). Ukrzaliznytsya. Postup chasu. 1991-1996. Materialy do istoriyi zaliznychnoho transportu Ukrayiny [Ukrzaliznytsia. The progress of time. 1991-1996. Materials on the history of railway transport in Ukraine]. Kyiv: Transport Ukrayiny [in Ukrainian].

Naporko, A. G. (1957). Zheleznodorozhnyy transport SSSR $v$ dokumentakh Kommunisticheskoy partii i Sovetskogo pravitel'stva [Railway transport of the USSR in the documents of the Communist Party and the Soviet government]. Moscow: Gosudarstvennoye transportnoye zheleznodorozhnoye izdatel'stvo [in Russian].

Osobova, Ye. (2009). «Luganskteplovoz» mezhdu sokrashcheniyem kazhdogo chetvertogo i polnoy ostanovkoy [«Luganskteplovoz» between the reduction of every fourth and a complete stop]. Ukrainskaya tekhnicheskaya gazeta Ukrainian technical newspaper. April 28. 18(70). p. 5. [in Russian].

PAO «Luganskteplovoz» narashchivayet tempy [PJSC «Luganskteplovoz» increases the pace]. (2013). Nasha gazeta - Our newspaper. December 17. 186(3849). Lugansk, p. 2. [in Russian].

Pavlyuk I. (2010). Auktsion nebachenoyi bezkoryslyvosti [Auction of unprecedented selflessness]. Ukrayins'ka tekhnichna hazeta - Ukrainian technical newspaper. June 22. No. 25-26 (129-130). p. 6 [in Ukrainian].

Pervyy Luganskiy [First Lugansk], (2009). Ukrainskaya tekhnicheskaya gazeta Ukrainian technical newspaper. April 2. 14(66). p. 3 [in Russian]. 
Postanova Kabinetu Ministriv Ukrayiny vid 26 chervnya 1993 r. No. 480 «Pro rozrobku i vyrobnytstvo u 1993-2000 rokakh mahistral'nykh vantazhnykh i pasazhyrs'kykh elektrovoziv» [Resolution of the Cabinet of Ministers of Ukraine of June 26, 1993 No. 480 "On development and production in 19932000 years of main freight and passenger electric locomotives"]. Retrieved from https://zakon.rada.gov.ua/laws/show/480-93-\%D0\%BF [in Ukrainian].

Rakov, V. A. (1990). Lokomotivy i motorvagonnyy podvizhnoy sostav zheleznykh dorog Sovetskogo Soyuza (1976-1985 gg.) [Locomotives and motorcar rolling stock of the railways of the Soviet Union (1976-1985)]. Moscow: Transport [in Russian].

Rakov, V. A. (1995). Lokomotivy otechestvennykh zheleznykh dorog (1845-1955 gg.) [Locomotives of domestic railways (1845-1955)]. Moscow: Transport [in Russian].

Rakov, V. A. (1999). Lokomotivy otechestvennykh zheleznykh dorog (1956-1975 gg.) [Locomotives of domestic railways (1956-1975)]. Moscow: Transport [in Russian].

Ruban, M. Yu. \& Baka, B. O. (2020). Formation and development of main-line electric locomotive engineering in independed Ukraine (1991-2008). Doslidzhennya $z$ istoriyi i filosofiyi nauky i tekhniky - Studies in history and philosophy of science and technology. 1(29). p.105-112. https://doi.org/10.15421/272013.

Rybinets, V. R. (1996). Luganskiye lokomotivy: lyudi, gody, fakty [Lugansk locomotives: people, years, facts]. Lugansk [in Russian].

Shvaiko, Y. (2003). Mesto na transportnom rynke [Place in the transport market]. Magistral. April 18, No. 30 (809). Kyiv, p. 6-7 [in Russian].

Spektor, V. (2009). V kontekste vremeni [In the context of time]. Ukrainskaya tekhnicheskaya gazeta - Ukrainian technical newspaper. February 5. No. 6 (58). p. 10 [in Russian].

Tsygankov-Serebryakov, Yu. V. (2006). Lyudi. Gody. Fakty. OAO «KHK» Luganskteplovoz» [People. Years. Data. OJSC «HC» Luganskteplovoz»]. Lugansk. [in Russian].

«Ukrzalíznitsya» zakupit 16 lokomotivov [«Ukrzaliznytsia» will purchase 16 locomotives] (2010). Ekonomicheskiye izvestiya - Economic news. October 18. No. 178 (1411). Kiev, p. 4 [in Russian].

Yurova, S. \& Spektor, V. (2011). Sergey Mikheyev: «U nas slavnoye proshloye i khoroshiye perspektivy» [Sergey Mikheev: "We have a glorious past and good prospects"]. Ukrainskaya tekhnicheskaya gazeta - Ukrainian technical newspaper. May 31. No. 20 (175). p. 5 [in Russian].

Zhdanov, G. V. (1981). Vernost' traditsiyam: Ocherk istorii Voroshilovgradskogo zavoda ordena Lenina i ordena Oktyabr'skoy revolyutsii teplovozostroitel'nogo zavoda im. Oktyabr'skoy revolyutsii [Fidelity to tradition: An outline of the history of the Voroshilovgrad plant of the Order of Lenin and the Order of the 
October Revolution of the Locomotive Plant named after October revolution]. Moskva: Mysl [in Russian].

Zhuzhgin, S. (1993). Elektrovoz 2000-go: baza zakladyvayetsya segodnya [Electric locomotive of 2000: the base is being laid today]. Magistral. August 20. No. 31(35). Kyiv, p. 8 [in Russian].

\section{Микола Рубан}

АТ «Укрзалізниця», Україна

\section{Передумови становлення та розвиток магістрального електровозобудування на Луганському тепловозобудівному заводі} (1957-2014)

Анотація. У статті здійснено спробу дослідити в хронологічному порядку історичні обставини становлення та розвитку магістрального електровозобудування на Луганському тепловозобудівному заводі (19572014 рр.). Проаналізовано обставини діяльності електровозного цеху Луганського заводу (1957-1967рр.), у рамках якої протягом 10 років здійснювалось виробництво екіпажних частин та вузлів легендарних електровозів ВЛ8 $i$ ВЛ10 для Новочеркаського та Тбіліського заводів. Наприкіниі 1980-х рр. у зв'язку з відсутністю твердої конвертованої валюти для імпорту тягового рухомого складу з Чехословаччини на хвилі економічної кризи СРСР, Луганський завод отримав замовлення на розробку та виробництво вантажопасажирських електровозів власної конструкиії. Однак, з проголошенням Незалежності Украӥни, через лобізм нового керівництва уряду, перспективні проекти луганських електровозів були відхилені, а базовим підприємством зі створення магістральних електровозів для українських залізниць був визначений Дніпровський електровозобудівний завод. Оскільки внаслідок нестабільної економічної ситуації в країні та відсутності иільового фінансування Дніпровський завод не спромігся налагодити серійне виробництво низки типів електровозів, ХК «Луганськтепловоз» спільно з Новочеркаським заводом розпочали виготовлення вантажних електровозів на технологічній основі російських локомотивів. Подальший розвиток та перспективи серійного електровозобудування на Луганському заводі був перерваний із загостренням військово-політичної ситуачії в регіоні. Однак, безумовно, щзо історичний досвід становлення вітчизняної науково-виробничої бази магістрального електровозобудування потребує свого належного осмислення в контексті сучасних тендениій імпорту тягового рухомого складу зі спробою подальшої локалізачї його виробництва в Україні.

Ключові слова: Луганський тепловозобудівний завод; транспортне машинобудування; магістральне електровозобудування; украйнські залізнииі 


\section{Николай Рубан}

АО «Укрзализныця», Украина

\section{Предпосылки становления и развитие магистрального электровозостроения на Луганском тепловозостроительном заводе (1957-2014)}

Аннотация. $B$ статье предпринята попьтка исследовать $в$
хронологическом порядке исторические обстоятельства становления $и$
развития магистрального электровозостроения на Луганском тепловозостроительном заводе (1957-2014 г2.). Проанализированьл обстоятельства деятельности электровозного иееха Луганского завода (1957 1967 г2.) в рамках которой в течение 10 лет осуществлялось производство экипажных частей и узлов легендарных электровозов ВЛЯ и ВЛ10 для Новочеркасского и Тбилисского заводов. $B$ кониее 1980-х г2. в связи $c$ отсутствием твердой конвертируемой валють для импорта тягового подвижного состава из Чехословакии на волне экономического кризиса СССР, Луганский завод получил заказ на разработку и производство грузопассажирских электровозов собственной конструкции. Однако, $c$ провозглашением независимости Украинь, через лоббизм нового руководства правительства, перспективные проекты луганских электровозов были отклонены, а базовым предприятием по созданию магистральных электровозов для украинских железных дорог был определен Днепровский электровозостроительный завод. Поскольку в результате нестабильной экономической ситуации в стране и отсутствия целевого финансирования Днепровский завод не смог наладить серийное производство ряда типов электровозов, ХК «Лугансктепловоз» совместно с Новочеркасским заводом начали изготовление грузовых электровозов на технологической основе российских локомотивов. Дальнейшее развитие и перспективы серийного электровозостроения на Луганском заводе были прерваны с обострением военно-политической ситуации в регионе. Однако, безусловно, что исторический опьт становления отечественной научно-производственной базы магистрального электровозостроения требует своего должного осмысления в контексте современных тенденций импорта тягового подвижного состава с попьткой дальнейшей локализации его производства $в$ Украине.

Ключевые слова: Луганский тепловозостроительный завод; транспортное машиностроение; магистральное электровозостроение; украинские железные дороги

Received 13.01.2020

Received in revised form 17.03.2020

Accepted 25.03.2020 